\title{
The Expanding Protection of Members of a Party's own Armed Forces UNDER INTERNATIONAL CRIMINAL LAW
}

Cóman Kenny* and Yvonne McDermott**

\begin{abstract}
Does international law govern how states and armed groups treat their own forces? Do serious violations of the laws of war and human rights law that would otherwise constitute war crimes or crimes against humanity fall squarely outside the scope of international criminal law when committed against fellow members of the same armed forces? Orthodoxy considered that such forces were protected only under relevant domestic criminal law and/or human rights law. However, landmark decisions issued by the International Criminal Court (ICC) and the Extraordinary Chambers in the Courts of Cambodia (ECCC) suggest that crimes committed against members of the same armed forces are not automatically excluded from the scope of international criminal law. This article argues that, while there are some anomalies and gaps in the reasoning of both courts, there is a common overarching approach under which crimes by a member of an armed group against a person from the same forces can be prosecuted under international law. Starting from an assessment of the specific situation of the victim, this article conducts an in-depth analysis of the concepts of hors de combat' and 'allegiance' for war crimes and that of the 'lawful target' for crimes against humanity, providing an interpretative framework for the future prosecution of such crimes.
\end{abstract}

\section{Introduction}

The protection of members of a state or armed group's own forces under international law has traditionally received little scholarly attention. ${ }^{1}$ Until recently, the common

\footnotetext{
* Assistant Co-Prosecutor, Extraordinary Chambers in the Courts of Cambodia. Email: comankenny@gmail.com.

** Professor of Law, Hillary Rodham Clinton School of Law, Swansea University. Email: Yvonne.McDermottRees@swansea.ac.uk. The authors would like to thank Daragh Murray, Ioannis Kalpouzos, and the anonymous peer-reviewer for very helpful comments on an earlier draft. The views expressed herein are those of the authors and do not reflect the views of any institution with which they are affiliated.

${ }^{1}$ A search of the leading textbooks, monographs, and journals on international humanitarian law reveal nothing written on this subject prior to 2017, with the exception of Peter Rowe, 'The Obligation of a State under International Law to Protect Members of its Own Armed Forces During Armed Conflict or Occupation' (2006) 9 Yearbook of IHL 3 and Sandesh Sivakumaran, The Law of Non-International Armed Conflict (Oxford: OUP, 2012), 246-249, arguing that certain provisions apply to intra-party
} 
assumption was that intra-armed group crimes were violations only under relevant domestic criminal law and/or human rights law, and thus fell outside the scope of international criminal law. ${ }^{2}$ Given that the definition of war crimes under international criminal law derives from international humanitarian law - which is understood as principally protecting civilians and members of the opposing armed forces who are hors de combat, as well as regulating conduct against adversaries on the battlefield - it would stand to reason that those actively participating in hostilities on behalf of an armed force or group will not be victims of war crimes where abuses have been committed against them by members of the same force or group. Similarly, given that crimes against humanity are committed as part of a widespread or systematic attack against a civilian population, combatants or fighters would traditionally have been considered to fall outside of the scope of such crimes. ${ }^{3}$ While human rights obligations continue to apply to states and armed groups in times of armed conflict, ${ }^{4}$ violations of human rights law do not fall within the ambit of international criminal law, unless the jurisdictional requirements of genocide, crimes against humanity, or war crimes are also met.

However, developments in the jurisprudence of the International Criminal Court (ICC) and the Extraordinary Chambers in the Courts of Cambodia (ECCC) suggest that crimes directed against members of the same armed forces can be considered violations of international criminal law. This article examines the ICC's conclusion that members of the same armed forces as the perpetrator can be victims of war crimes and the ECCC's decision that such persons can be the object of an attack against a civilian population

relationships. The topic still remains under-examined; for example, it is discussed briefly in only one contribution (Patricia Sellers and Indira Rosenthal, 'Rape and Other Sexual Violence', 343-368, at 356) to the landmark 1754-page The 1949 Geneva Conventions: A Commentary (Andrew Clapham, Paola Gaeta, and Marco Sassoli (eds), Oxford: OUP, 2015).

${ }^{2}$ Antonio Cassese, International Criminal Law (2 ${ }^{\text {nd }}$ edn, Oxford: OUP, 2008), 82, arguing that 'crimes committed by servicemen against their own military (whatever their nationality) do not constitute war crimes. Such offences may nonetheless fall within the ambit of the military law of the relevant belligerent.' Cf. Sivakumaran, ibid.

${ }^{3}$ The definition of 'civilian population' for the purposes of crimes against humanity in international criminal law has been informed by Article 50 of Additional Protocol I, which defines a civilian as any person not falling within any of the categories of person set out in Articles 4A(1), (2), (3) and (6) of the Third Geneva Convention or Article 43 of Additional Protocol I. See for example, Prosecutor v. Blaškić, Judgment, Case No. IT-95-14-A, 29 July 2004, paras. 110-116; Prosecutor v. Bemba, Judgment, Case No. ICC-01/05-01/08-3343, 21 March 2016, para. 152.

${ }^{4}$ It is well-established that states' human rights obligations continue to apply in armed conflict: see, for example, the International Court of Justice's Advisory Opinion on Legal Consequences of the Construction of a Wall in the Occupied Palestinian Territory, 9 July 2004, ICJ Reports 2004; Human Rights Committee, General Comment 29, States of Emergency (Article 4), UN Doc. CCPR/C/21/Rev.1/Add.11 (2001) para. 3; Daragh Murray et al., Practitioners' Guide to Human Rights Law in Armed Conflict (Oxford: OUP, 2016). On armed groups' human rights obligations, see Daragh Murray, Human Rights Obligations of Non-State Armed Groups (Oxford: Hart, 2016). 
for the purposes of crimes against humanity. Having critiqued why we consider the approach of the ICC and ECCC in their respective decisions to have come to the correct conclusion but by the wrong means, we examine the contexts in which members of the same armed forces could be considered victims of international crimes falling under the jurisdiction of international criminal tribunals. We argue in favour of an approach that examines the specific situation of a victim at the relevant time under the rubric of both crimes against humanity and war crimes. For war crimes, this examination focuses on whether the victim was hors de combat at the time of their victimization, and their allegiance to the armed group in question. For crimes against humanity, this involves analysing whether the victim was a lawful target at the time of the attack.

\section{Applying International Criminal Law to Attacks against Members of the Same Armed Force or Group: The Jurisprudence of the ICC and ECCC}

At approximately the same time, the International Criminal Court and Extraordinary Chambers in the Courts of Cambodia both addressed the same question: could crimes committed by members of military forces against individuals within the same armed group fall within their jurisdiction? In the Ntaganda trial, the ICC had to determine whether acts of rape and sexual slavery committed during a non-international armed conflict in the Democratic Republic of the Congo by UPC/FPLC soldiers against child soldiers recruited to those armed groups constituted war crimes under Article 8 of the Rome Statute. ${ }^{5}$ At the ECCC, investigations in Cases 003, 004, and 004/2 involved the Khmer Rouge's 'purge' of its own cadres and soldiers, involving mass extrajudicial arrests, detentions and executions. Despite there being no allegations of an attack directed solely at members of the armed forces by the Khmer Rouge, the International Co-Investigating Judge (ICIJ) requested submissions on whether an attack by a state or

\footnotetext{
${ }^{5}$ The Patriotic Forces for the Liberation of the Congo (FPLC), the military wing of the Union of Congolese Patriots (UPC), the were engaged in an armed conflict in Ituri, a region in north-eastern Democratic Republic of the Congo from 2002-2003. Bosco Ntaganda is the former Deputy Chief of Staff of the FPLC. There are three separate decisions on this issue, from different stages of the proceedings: Prosecutor v. Ntaganda, Decision Pursuant to Article 61(7)(a) and (b) of the Rome Statute on the Charges of the Prosecutor Against Bosco Ntaganda, Case No. ICC-01/04-02/06-309, 9 June 2014, para. 77 ('Ntaganda Pre-Trial Chamber decision'); Prosecutor v. Ntaganda, Second decision on the Defence's challenge to the jurisdiction of the Court in respect of Counts 6 and 9, Case No. ICC-01/04-02/06-1707, 4 January 2017 ('Ntaganda Trial Chamber decision'); Prosecutor v. Ntaganda, Judgment on the appeal of Mr Ntaganda against the "Second decision on the Defence's challenge to the jurisdiction of the Court in respect of Counts 6 and 9", Case No. ICC-01/04-02/06-1962, 15 June 2017 ('Ntaganda Appeals Chamber decision').
} 
organisation against its own forces could fulfil the chapeau requirement for crimes against humanity of an attack against 'any civilian population'. 6

Three separate chambers of the ICC (a Pre-Trial Chamber, Trial Chamber, and the Appeals Chamber) all reached the conclusion that the sexual crimes at issue did constitute war crimes, albeit on somewhat different grounds. The Pre-Trial Chamber founded its conclusion on an analysis of whether the victims were directly participating in hostilities, while the Trial Chamber focused instead on a literal reading of the Rome Statute and the jus cogens nature of the violations in question, an approach broadly followed by the Appeals Chamber. At the ECCC, the ICIJ found that between 1975 and 1979 (the period relevant to the temporal jurisdiction of the ECCC), an attack by a state or organised group against its own forces satisfied the chapeau requirement of an attack against a 'civilian population' under customary international law. ${ }^{7}$ Given the stage of proceedings in the cases at which it was raised propio motu by the ICIJ, the Pre-Trial Chamber denied any appeal against the decision because of the declaratory nature of the relief requested. ${ }^{8}$ Therefore, unlike the ICC's decisions in Ntaganda, the ECCC's decision was not subject to any further litigation and the likelihood of it surviving an appellate challenge is consequently unclear.

This section analyses the decisions of each of the chambers of the ICC and the ICIJ in turn. It argues that, of the differing approaches taken by the ICC, that of the Pre-Trial Chamber is most convincing, although not without its weaknesses. We further posit that, while its conclusion is defensible, the ECCC ICIJ's decision fails to properly articulate the customary international law basis upon which it was founded and contradicts earlier ECCC jurisprudence without expressly acknowledging any such departure.

\section{A. Victims as not being Direct Participants in Hostilities: The ICC Pre-Trial Chamber's Confirmation Decision}

\footnotetext{
${ }^{6}$ Cases 003 and 004, Call for Submissions by the Parties in Cases 003 and 004 and Call for Amicus Curiae Briefs, Case File No. 003/07-09-2009-ECCC-OCIJ, 19 April 2016.

${ }^{7}$ Cases 003 and 004, D191/18: Notification on the Interpretation of 'Attack Against the Civilian Population' in the Context of Crimes Against Humanity with regard to a State's or Regime's Own Armed Forces, Case File No. 003/07-09-2009-ECCC-OCIJ, 7 February 2017, para. 69 ("ICIJ Crimes Against Humanity Decision").

${ }^{8}$ Cases 003 and 004, D347.1/1/7: Decision On Appeal Against The Notification On The Interpretation Of 'Attack Against The Civilian Population' In The Context Of Crimes Against Humanity With Regard To A State's Regime Own Armed Forces, Case File No. 003/07-09-2009-ECCC-OCIJ, 30 June 2017.
} 
At the outset of the case against Ntaganda, Pre-Trial Chamber II confirmed charges of rape and sexual violence committed against child soldiers. The Chamber began by invoking the prohibition on the recruitment or use of child soldiers under the age of 15 , which is a war crime under Article 8 of the Statute. ${ }^{9}$ It noted that if the Court were to exclude child soldiers as victims of sexual violence under Article 8, merely by virtue of their membership of an armed group, it would be contrary to the rationale underpinning the prohibition on their recruitment. ${ }^{10}$

Nevertheless, the Chamber recalled that combatants (including child soldiers) in noninternational armed conflicts lose their protection under international humanitarian law when they directly participate in hostilities. ${ }^{11}$ Reconciling these two seemingly opposing conclusions, the Chamber considered that those members of armed forces subjected to rape or sexual violence could not be actively participating in hostilities 'during the specific time when they were subject to acts of [a] sexual nature, including rape'. ${ }^{12}$ To justify this, the Chamber paid particular attention to the fact that acts of sexual violence 'involve elements of force/coercion or the exercise of rights of ownership [which] logically preclude active participation in hostilities at the same time'. ${ }^{13}$ On that basis, it concluded that the Court was not barred from exercising jurisdiction over the war crimes of rape and sexual slavery committed against UPC/FPLC child soldiers. ${ }^{14}$

\section{$i$. The continuous combat function}

The Pre-Trial Chamber's findings rightly recognised that Common Article 3 only protects those persons not directly participating in hostilities, ${ }^{15}$ and used that fact to note that the alleged victims of sexual violence in the Ntaganda case could not have been actively participating in hostilities at the time that they were subjected to sexual violence. This position is intuitively attractive, but overlooks an important point. The International Committee of the Red Cross (ICRC)'s authoritative guidance on the

\footnotetext{
${ }^{9}$ Ntaganda Pre-Trial Chamber decision (n 5), para. 78.

${ }^{10} I d$.

${ }^{11}$ Ibid., para. 79.

${ }^{12} I d$.

${ }^{13} I d$.

${ }^{14}$ Ibid., para. 80.

${ }^{15}$ Common Article 3 of the Geneva Conventions refers to 'persons taking no active part in the hostilities' in setting out minimum standards (Article 3(1)), and further notes, in Article 3(2), that 'the wounded and sick shall be cared for.
} 
notion of direct participation in hostilities recognises the so-called 'revolving door' situation, where an individual loses their protection under international humanitarian law for such time as they are participating in hostilities, and gains it again when they cease directly participating in hostilities. ${ }^{16}$ There is an exception, however; the interpretive guidance clarifies that the revolving door scenario only applies to those persons who are not 'members' of an armed group. ${ }^{17}$ Such membership, in turn, is dependent on whether a person 'assumes a continuous combat function for the group involving his or her direct participation in hostilities'. ${ }^{18}$ The continuous combat function overcomes the 'revolving door' phenomenon by examining certain participants' overall participation in hostilities, rather than being based solely on an examination of individual acts. The recognition that those fighters and members of an armed wing of an armed group who carry out a continuous combat function lose their protection as civilians, even in those moments when they are not expressly carrying out military functions, bears particular significance for the practical application of international humanitarian law. The Pre-Trial Chamber neglected to discuss the possible applicability - or otherwise - of the continuous combat function concept to the particular victims in the Ntaganda case.

\section{ii. The scope of the Pre-Trial Chamber's decision}

The Pre-Trial Chamber's conclusion raised two interesting issues on the potential scope and reach of its conclusions that were not addressed in the decision. The first was whether its findings on direct participation in hostilities (or the lack thereof, in times of victimisation) could lead to a consequential greater protection for fighters in noninternational armed conflicts than for those in international armed conflicts. This is because the law relating to international armed conflicts merely distinguishes between 'combatants' and 'civilians', while the distinction in non-international armed conflicts is founded on the notion of active or direct participation in hostilities. ${ }^{19}$ By limiting its analysis to the notion of direct participation in hostilities, and finding that the alleged victims in this case were protected because they could not have been participating in

\footnotetext{
${ }^{16} \mathrm{ICRC}$, Interpretive guidance on the notion of direct participation in hostilities under international humanitarian law (Geneva: ICRC, 2009), 70-71.

${ }^{17}$ Ibid., 71-73.

${ }^{18}$ Ibid., 33.

${ }^{19}$ Article 50(1) of Additional Protocol I defines civilians as persons who do not belong to one of the categories of persons referred to in Article 4(A)(1), (2), (3), and (6) of the Third Geneva Convention. See also Additional Protocol I, Article 43.
} 
hostilities at the time of their victimisation, the Pre-Trial Chamber left unanswered the question of whether combatants in international armed conflicts were similarly protected when not carrying out combat functions.

The second potential consequence left unexamined by the Chamber was the impact of its decision on the scope of the crime of recruiting and using child soldiers. The Lubanga Trial Chamber judgment took an expansive interpretation of the notion of active participation in hostilities, in order to bring as many victims of forced recruitment as possible within the scope of the crime under Articles 8(2)(b)(xxvi) and 8(2)(e)(vii). ${ }^{20}$ It noted that, "[t]hose who participate actively in hostilities include a wide range of individuals, from those on the front line (who participate directly) through to the boys or girls who are involved in a myriad of roles that support the combatants. ${ }^{21}$ The Ntaganda Pre-Trial Chamber's findings on direct participation in hostilities raised an issue of whether children who were primarily recruited to an armed force for the purpose of sexual slavery fell outside the scope of the prohibition of conscription of child soldiers. This point was again unaddressed by the Pre-Trial Chamber.

Notwithstanding those unanswered questions, the Pre-Trial Chamber's decision was met with cautious approval from academic commentators. ${ }^{22}$ In section 4 below, we discuss this commentary, and address the previously mentioned issues of the continuous combat function and the scope of the Pre-Trial Chamber's decision.

\section{B. War Crimes can be Committed against Members of the Same Armed Forces: The}

\section{Trial Chamber's Decision}

Following the Pre-Trial Chamber's Confirmation Decision, the Ntaganda Defence contested the Court's jurisdiction over the counts of rape and sexual slavery. ${ }^{23} \mathrm{In}$

\footnotetext{
${ }^{20}$ Prosecutor v. Lubanga, Judgment pursuant to Article 74 of the Statute, Case No. ICC-01/04-01/062842, 14 March 2012.

${ }^{21}$ Ibid., para. 628.

${ }^{22}$ Tilman Rodenhäuser, 'Squaring the Circle? Prosecuting Sexual Violence against Child Soldiers by their "Own Forces"' (2016) 14 Journal of International Criminal Justice 171; Rosemary Grey, 'Sexual Violence against Child Soldiers: The Limits and Potential of International Criminal Law' (2014) 16 International Feminist Journal of Politics 601; Patricia Viseur Sellers, 'Ntaganda: Re-Alignment of a Paradigm', Proceedings of the San Remo Round Table on 'The Additional Protocols 40 Years Later New Conflicts New Actors New Perspectives' (San Remo: IIHL, 2017), available online at http://iihl.org/wpcontent/uploads/2018/07/The-Additional-Protocols-40-Years-Later-New-Conflicts-New-Actors-NewPerspectives_2.pdf, 116 .

${ }^{23}$ Prosecutor v. Ntaganda, Application on behalf of Mr Ntaganda challenging the jurisdiction of the Court in respect of Counts 6 and 9 of the Document containing the charges, Case No. ICC-01/04-02/06804, 1 September 2015.
} 
response, Trial Chamber VI came to the same conclusion as the Pre-Trial Chamber but relied on a completely different basis, looking to the literal wording of the provisions of the Rome Statute at issue and the jus cogens nature of the prohibition against rape.

First, the Chamber noted that whilst Articles 8(2)(a) and (c) referred to specific victim status requirements in their chapeau, namely that the person be protected by the relevant provisions of the Geneva Conventions under paragraph (a) or be taking no active part in hostilities under paragraph (c), no such limitations could be found in subparagraphs (b) and (e), ${ }^{24}$ the provisions under which Ntaganda had been charged. It added that it would run contrary to the internal structure of the war crimes prohibition in the ICC Statute to incorporate the status requirements of Articles 8(2)(a) and (c) (for grave breaches and violations of Common Article 3) into Articles 8(2)(b) and (e). ${ }^{25}$

Whilst logically appealing, the Chamber's position is less than convincing, given that it had not been suggested that the charges confirmed against Ntaganda must be understood as being serious violations of Common Article 3 or grave breaches. Rather, the Defence had argued that the provisions of Article 8(2)(e) (and, by implication, Article 8(2)(b)) must be interpreted in accordance with their chapeau, which makes explicit reference to 'the established framework of international law' ${ }^{26}$ Hence, each offence under these provisions must be examined in light of the treaty or customary provision from which it is derived in order to determine its scope and the material elements of the crime. ${ }^{27}$

The crimes set out in Article 8(2)(e) are primarily derived from Additional Protocol II (AP II) to the Geneva Conventions. ${ }^{28}$ Article 4 of AP II, on fundamental guarantees (which include the prohibition of rape and all forms of slavery), is limited in its application to '[a]ll persons who do not take a direct part or who have ceased to take part in hostilities'. ${ }^{29}$ It could be argued that Article 4(3) - which states that children

\footnotetext{
${ }^{24}$ Ntaganda Trial Chamber decision (n 5), para. 40.

${ }^{25} I d$.

${ }^{26}$ Emphasis added. This reference to the established framework of international law is found in both 8(2)(b) and (e) of the ICC Statute, and the corresponding provisions of the ICC Elements of Crimes.

${ }^{27}$ Michael Cottier, 'Article 8', in Otto Triffterer and Kai Ambos (eds.), Commentary on the Rome Statute of the International Criminal Court: Observers' Notes, Article by Article (Oxford: Hart/Beck, $3^{\text {rd }}$ edn., 2016), 317.

${ }^{28}$ Ibid, 318.

${ }^{29}$ Article 4(1), Additional Protocol II. Article 4(2), outlining the fundamental guarantees, further confirms that those acts are prohibited 'against the persons referred to in paragraph 1 '.
} 
affected by hostilities are entitled to special care and protection ${ }^{30}$ - ensures that child victims are therefore covered by the war crimes provisions derived from Article 4(2), regardless of their ongoing participation in hostilities. ${ }^{31}$ However, Article 4(3)(d) itself undermines this argument by clarifying that the special protection afforded to children will continue to apply to those (unlawfully recruited) child soldiers who have taken direct part in hostilities if they 'are captured'. The term 'captured' here implies the taking by force of such children by the adverse party. The relevance of former child soldiers' capture is important, because it emphasizes that their protection derives from their status as individuals no longer taking part in hostilities. Thus, Additional Protocol II, as the relevant framework of international law, clearly protects only those individuals who are not directly participating in hostilities, including those who have ceased to do so.

While it might be suggested that customary international law supports the Trial Chamber's interpretation, no reference was made to state practice or opinio juris to support such an argument. Instead, the Chamber noted the widespread prohibition of rape under international humanitarian law. ${ }^{32}$ Whilst acknowledging that most sources of that prohibition referred to civilians and those hors de combat, it concluded that they nevertheless did not limit the scope of the prohibition. ${ }^{33}$ The Chamber also referred to the Martens Clause - which mandates that those situations not explicitly covered by treaty shall be governed by custom, humanity, and the dictates of the public conscience - and recalled that the fundamental guarantees are prohibited " "at any time and in any place whatsoever" and as such apply to, and protect, all persons in the power of a Party to the conflict.' 34

This expansive reading of the established framework of international law is unpersuasive for two reasons. First, the Martens Clause is a general principle of international humanitarian law which guides combatants and protects populations and belligerents in the absence of rules expressly prohibiting certain conduct. While the

\footnotetext{
${ }^{30}$ Article 4(3), Additional Protocol II.

${ }^{31}$ Sellers (n 22), 132.

${ }^{32}$ Ntaganda Trial Chamber decision, para. 46.

${ }^{33}$ Ntaganda Trial Chamber decision, paras 46-47.

${ }^{34} \mathrm{Id}$. (referring to Article 75 of Additional Protocol I, noting that it "refers to " $a$ Party to the conflict" (emphasis added) and therefore does not limit the fundamental guarantees to persons in the power of the opposing party.')
} 
Trial Chamber's decision is not the first time that the Clause has been used to enable international judges to engage in the progressive development of international humanitarian law, ${ }^{35}$ this has not been without controversy. ${ }^{36}$

Second, the Chamber's reference to the broad wording of the fundamental guarantees provisions is premised on Additional Protocol I, which applies to international armed conflicts. It therefore overlooks the important fact that the fundamental guarantees provision in AP II, which is the more appropriate legal instrument in this case as it applies to non-international armed conflicts, does have a limiting clause. As discussed above, Article 4 of AP II explicitly only applies to those not directly participating in hostilities.

The Chamber further noted that there could be no military justification for rape and sexual slavery. ${ }^{37}$ This is correct, but it does not follow that any conduct not mandated by military justification in an armed conflict can automatically be classified as a war crime. Additionally, the Chamber relied on the ICRC's recently updated commentary to the first Geneva Convention, in particular its commentary to Common Article $3 .{ }^{38}$ In this study, the ICRC argued that 'armed forces of a Party to the conflict benefit from the application of Common Article 3 by their own Party' ${ }^{39}$ and that ' $[\mathrm{t}]$ he fact that the ... abuse [is] committed by their own Party should not be a ground to deny such persons the protection of Common Article 3. ${ }^{40}$ The ICRC cited the well-known phrase from the International Court of Justice's Nicaragua decision that Common Article 3 reflects a 'minimum yardstick' of treatment in support of this interpretation. ${ }^{41}$ Interestingly, the ICRC also cited the ICC Pre-Trial Chamber's decision in Ntaganda in support of this, ${ }^{42}$ while the Prosecutor, in turn, then relied on the new ICRC commentary to buttress its

\footnotetext{
${ }^{35}$ Jared Wessel, 'Judicial Policy-Making at the International Criminal Court: An Institutional Guide to Analyzing International Adjudication’ (2006) 44 Columbian Journal of Transnational L. 377, 390.

${ }^{36}$ Beth van Schaak, 'Crimen Sine Lege: Judicial Lawmaking at the Intersection of Law and Morals', (2007) Santa Clara University School of Law Legal Studies Research Papers Series, Working Paper No. 07-47, 26-27.

${ }^{37}$ Ntaganda Trial Chamber decision (n 5), paras 48-49.

${ }^{38}$ ICRC, Commentary on the First Geneva Convention: Convention I for the Amelioration of the Condition of the Wounded and Sick in Armed Forces in the Field ( $2^{\text {nd }}$ edition, Cambridge: Cambridge University Press, 2016).

${ }^{39}$ Ibid., para. 547.

${ }^{40} I d$.

${ }^{41}$ Id. (citing Case Concerning Military and Paramilitary Activities In and Against Nicaragua (Nicaragua v. United States of America) (1986) ICJ 14, 27 June 1986, paras. 218-219).

${ }^{42}$ ICRC (n 38), para. 547.
} 
own arguments before the Appeals Chamber. ${ }^{43}$ This symbiotic and mutually reinforcing relationship between the ICRC and the ICC in expanding the scope of longstanding interpretations of international humanitarian law has not been lost on commentators. ${ }^{44}$

The Chamber's conclusion on the jus cogens status of the prohibition of both slavery (encompassing sexual slavery) and rape under international law is of further note. ${ }^{45}$ The Chamber's finding that slavery is a jus cogens norm is supported by citing the Barcelona Traction case from $1970 .{ }^{46}$ This is remarkable, as the International Court of Justice's first reference to the concept of jus cogens norms was not until 16 years later, in its Nicaragua judgment. ${ }^{47}$ Paragraphs 33 and 34 of Barcelona Traction, as cited by the Trial Chamber, make no mention of jus cogens and instead discuss the concept of erga omnes. ${ }^{48}$ On the specific prohibition of sexual slavery as a jus cogens norm, the Chamber cited a 1998 report of the Special Rapporteur on Contemporary Forms of Slavery ${ }^{49}$ and the Special Court for Sierra Leone's Brima judgment. ${ }^{50}$ The Brima judgment cited a 2000 report of the Special Rapporteur on Contemporary Forms of Slavery, which in turn cited its own 1998 report as authority for the jus cogens conclusion. In other words, the Chamber's conclusions on slavery as a jus cogens norm are bolstered by a single reference that does not support this conclusion, and its conclusions on sexual slavery as a jus cogens norm derives from a single source which provides no authority for this assertion. ${ }^{51}$ Its findings that the prohibition of rape has

\footnotetext{
${ }^{43}$ Prosecutor v. Ntaganda, Prosecution's Response to Ntaganda's 'Appeal from the Second Decision on the Defence's Challenge to the Jurisdiction of the Court in respect of Counts 6 and 9', Case No. ICC01/04-02/06-1794, 17 February 2017.

${ }^{44}$ Michael Newton, 'Contorting Common Article 3: Reflections on the Revised ICRC Commentary' (2017) 45 Ga. J. Int’l \& Comp. L. 513, 517-522.

45 Judge Ozaki 'reserve[d] her views' on the question of whether the prohibition of rape was a jus cogens norm, finding the statement on this issue to be 'unnecessary to the reasoning' and potentially misleading.

${ }^{46}$ Barcelona Traction, Light and Power Company, Limited (Belgium v. Spain) (1970) ICJ 3, 5 February 1970 .

${ }^{47}$ Nicaragua case (n 41), para. 190.

${ }^{48}$ Barcelona Traction case (n 46), paras 33 and 34. Para. 33 discusses the nature of erga omnes norms, while para. 34 discusses the origins of erga omnes from international law, as well as the principles and rules on human rights (including slavery and racial discrimination).

${ }^{49}$ Final report submitted by Special Rapporteur Gay J. McDougall, Contemporary Forms of Slavery Systematic rape, sexual slavery and slavery like practices during armed conflict, Commission on Human Rights, Sub-Commission on Prevention of Discrimination and Protection of Minorities, Fiftieth session, E/CN.4/Sub.2/1998/13, 22 June 1998, para. 30

${ }^{50}$ Prosecutor v. Brima, Kamara, and Kanu, Judgment, Case No. SCSL-04-16-T, 20 June 2007, para. 705, citing Special Rapporteur on Contemporary Forms of Slavery, ibid., 6 June 2000, para. 51.

${ }^{51}$ The Special Rapporteur's 1998 report (n 49) makes reference only to general sources on the prohibition of slavery under international law (e.g. 'M. Cherif Bassiouni, International Crimes: Digest/Index of
} 
attained jus cogens status under international law appear to be similarly unsupported by primary international legal sources. The only authorities for this assertion were two pieces of academic scholarship, both of which recognise that the prohibition of rape is not yet a jus cogens norm, but argue that it should be, ${ }^{52}$ or is likely to be recognised as such in the future. ${ }^{53}$ Thus, the Chamber's conclusion that the established framework of international law justified its interpretation appears not to be fully supported by the authorities it cited.

\section{Confirming the Trial Chamber's approach: The Appeals Chamber's Decision}

In June 2017, the Appeals Chamber issued its judgment on the Defence appeal against the Trial Chamber's findings, upholding the decision. The Appeals Chamber found no error in the Trial Chamber's interpretation that neither the ordinary meaning, the context, nor the drafting history of Articles 8(2)(b) and (e) required the victims to be 'protected persons in the (limited) sense of the grave breaches or Common Article 3'. ${ }^{54}$

The Appeals Chamber, like the Trial Chamber, found no evidence that the drafters positively sought to limit the scope of war crimes. ${ }^{55}$ However, this is a problematic interpretation from the point of view of the principle of legality and the limits of judicial law-making. It should surely be assumed that the drafters were mindful of the existing limited scope of international humanitarian law when enumerating the crimes under Articles 8(2)(b) and (e). That they did not expressly refer to those limits is not a convincing reason to expand the scope of the law beyond them, particularly given the reference to the 'established framework of international law' inserted into both provisions. Observers present at the drafting of the Statute were of the view that this phrase was added precisely 'to exclude an all too progressive interpretation' of those sub-paragraphs, and to underline that the offences must be interpreted in accordance with established international humanitarian law. ${ }^{56}$

\footnotetext{
International Instruments 1815-1985, vol. 1, 1986, 419 and main report, note 14 (detailing the incremental history of the international abolition of slavery)', and to sources outlining practices of sexual slavery, for example in Japan and the former Yugoslavia.

52 Kelly Dawn Askin, War Crimes against Women: Prosecutions in International War Crimes Tribunals (Leiden: Martinus Nijhoff Publishers 1997), 242.

${ }^{53}$ David S. Mitchell, 'The Prohibition of Rape in International Humanitarian Law as a Norm of Jus Cogens: Clarifying the Doctrine' (2005) 15 Duke J. Comp. \& Int'l L. 219.

${ }^{54}$ Ntaganda Appeals Chamber decision (n 5), para. 51, citing Ntaganda Trial Chamber decision (n 5), para. 44.

${ }^{55}$ Ntaganda Appeals Chamber decision (n 5), para. 50.

${ }^{56}$ Cottier (n 27), 354.
} 
Additionally, both the Trial Chamber and Appeals Chamber findings answer the wrong question - the issue facing both Chambers was not, as suggested, whether the status requirements of grave breaches or Common Article 3 applied to Articles 8(2)(b) and (e). Instead, the question was whether Articles 8(2)(b) and (e) themselves limited who could be considered a victim of such crimes, read in accordance with the broader framework of international humanitarian law. As discussed above, Additional Protocol II (from which Article 8(2)(e) derives) limits the scope of the fundamental guarantees to those not directly participating in hostilities. ${ }^{57}$ To acknowledge this fact is not to transpose the requirements of Article 8(2)(c) into Article 8(2)(e). It simply recognizes that the two sub-paragraphs relate to different classes of war crimes in non-international armed conflicts - those that are breaches of Common Article 3 (Article 8(2)(c)) and other war crimes in non-international armed conflicts (Article 8(2)(e)). Despite noting the fact that victims of the war crimes of rape or sexual slavery are usually civilians or persons hors de combat, the Appeals Chamber found 'no conceivable reason' to conclude that there were any status requirements for victims of such conduct. ${ }^{58}$

The Appeals Chamber further clarified that the inclusion of intra-party sexual violence as a war crime did not impinge upon domestic criminal law, because the nexus to an armed conflict distinguished this conduct as an international crime, as opposed to a purely domestic criminal law matter. ${ }^{59}$ It also acknowledged, however, 'the seemingly unprecedented nature' of its conclusions and that there were concerns that this could be seen as an exercise in judicial activism or expansionism. ${ }^{60}$ This issue is addressed further in section 3 below.

\section{One's own armed forces or group as a 'civilian population': The ECCC International Co-Investigating Judge's Decision on Crimes against Humanity}

There are two possible ways in which the question of whether crimes by individuals in an armed force committed against fellow members of the armed group are punishable under the rubric of crimes against humanity arises: where combatants are (i) victims of an attack against a civilian population, and (ii) the object of an attack. In respect of the former, the ECCC - in line with the jurisprudence of the ad hoc tribunals - have held

\footnotetext{
${ }^{57}$ See above, text to $\mathrm{n} 29$.

${ }^{58}$ Ntaganda Appeals Chamber decision (n 5), para. 64.

${ }^{59}$ Ntaganda Appeals Chamber decision (n 5), para. 68.

${ }^{60}$ Ibid, para. 67.
} 
that combatants can be victims within the context of a broader attack on a population. ${ }^{61}$ With regard to the latter, the targeting of soldiers in a specific attack has not been considered in terms of its compatibility with the concept of an attack against a civilian population by any international tribunal to date.

In a relatively brief decision, the International Co-Investigating Judge (ICIJ) concluded that members of an armed group or state armed forces subjected to an attack by members of the same group could satisfy the definition of a 'civilian population'. The interpretive methodology employed to reach this conclusion was, however, questionable. ${ }^{62}$ Having invoked Article 31 of the Vienna Convention on the Law of Treaties, which applies to convention texts, Article 5 of the ECCC Statute dealing with crimes against humanity should have been the focus of interpretation. Yet, the ICIJ declared that he was 'interpreting the law of [crimes against humanity] consistently with [its] object and purpose'. ${ }^{63}$ Assessing the state of customary international law is not, however a question of interpretation. Rather, it requires an examination of state practice and opinio juris in order to determine the customary definition applicable at the time. ${ }^{64}$ Instead of using the customary definition of crimes against humanity as a check on the textual interpretation of Article 5, the ICIJ employed the principle of legality to check his interpretation of customary international law. ${ }^{65}$ While this has been described as 'covering the bases', ${ }^{66}$ the ICIJ's approach was confusing. Arguably, this method may have been adopted in order to mask the dearth of state practice and opinio juris supporting the decision.

The ICIJ based his decision on a review of (a) the purpose of the law of crimes against humanity; (b) the pre-1975 interpretation of crimes against humanity in international law; and, (c) the post-1975 interpretation.

First, the ICIJ characterised the normative development of crimes against humanity referring to the UN War Crimes Commission (UNWCC) and the Nuremberg Charter -

\footnotetext{
${ }^{61}$ Case 002/1, Appeal Judgment, 002/19-09-2007-ECCC/SC, 23 November 2016, para. 738, citing Prosecutor v Blaškić, Judgement, IT-95-14-A, 29 July 2004, para. 113.

${ }^{62}$ See, Nina Jørgensen, The Elgar Companion to the Extraordinary Chambers in the Courts of Cambodia (Cheltenham: Edward Elgar, 2018) 224.

${ }^{63}$ ICIJ Crimes Against Humanity Decision (n 7) para. 55.

${ }^{64}$ Case 001, Appeal Judgement, 001/18-07-2007-ECCC/SC, 3 February 2012, para. 93.

65 Jørgensen (n 62) 224.

${ }^{66}$ Ibid.
} 
as an advancement in the law to address atrocities against civilian populations, including a state's own nationals. ${ }^{67}$ The ICIJ ruled that before then, the laws of war were narrowly formulated such that victims who were nationals of the perpetrating state were not protected from acts or omissions that would be war crimes if committed against enemy nationals. ${ }^{6}$

Given the temporal period of the ECCC, the pre-1975 definition was key to interpreting the applicable definition of crimes against humanity. The ICIJ began by considering the interpretation of the term 'civilian population' in post-World War II. Significantly, and despite quoting the work of the UNWCC when defining the purpose of crimes against humanity, the ICIJ did not refer to any UNWCC documentation relating to the interpretation of the term 'civilian population'. This is striking, as the ICIJ's task was to define customary international law at the relevant time. Moreover, the relevance of such documentation should be considered in light of the Supreme Court Chamber's assessment in the Case 001 Appeal Judgment that, in light of the difficulty in prosecuting international crimes, the requirement of opinio juris may be more important than state practice. ${ }^{69}$ Notably, the UNWCC stated that ' $[\mathrm{t}]$ he words "civilian population" [in Article 6(c) of the Nuremberg Charter] appear to indicate that "crimes against humanity' are restricted to inhumane acts committed against civilians as opposed to members of the armed forces'. ${ }^{70}$ This was based on a document agreed by the UNWCC's Legal Committee which concluded that:

"crimes against humanity" of the murder type are offences committed against civilian populations. Crimes against members of belligerent forces are outside the scope of this type of crime; as regards crimes of the persecution type, the Committee assumes that the intention is to exclude also this type of crime, though the wording is not quite clear. ${ }^{71}$

Two important points flow from this 1946 statement: (i) the extent to which the concept of crimes against humanity was intertwined with the existence of an armed conflict, and the resulting impact on interpreting the victim/object of an attack against a civilian

\footnotetext{
${ }^{67}$ ICIJ Crimes Against Humanity Decision (n 7) paras 25-26.

${ }^{68}$ Ibid., para. 23.

${ }^{69}$ Case 001 Appeal (n 64) para. 93.

${ }^{70}$ UNWCC, 'History of the United Nations War Crimes Commission and the Development of the Laws of War (1948) 193 (original emphasis). See also, p. 178.

${ }^{71}$ UNWCC, 'General Propositions defining the term "Crimes against Humanity" under the Charters of the International Military Tribunals and the Control Council Law No. 10' (30 May 1946) C.201 para. 4.
} 
population; and (ii) the split conception of crimes against humanity into 'murder type' offences and 'persecution type' offences.

(i) Interpreting the victim/object of an attack against a civilian population given the interlinked nature of crimes against humanity and armed conflict

The UNWCC's use of the term 'belligerent forces' demonstrates how crimes against humanity in 1946 were inextricably bound to the existence of an armed conflict. This is exemplified by the UNWCC's declaration that crimes against humanity 'denotes a particular type of war crime'. ${ }^{72}$

Indeed, the International Military Tribunal (IMT) judgment demonstrates how the notions of crimes against humanity and war crimes were, in practice, dealt with in an overlapping manner. To begin with, the Nuremberg indictment had declared that ' $[t]$ he Prosecution will rely upon the facts pleaded under Count Three as also constituting Crimes against Humanity. ${ }^{73}$ Count Three deals with, inter alia, the "murder and illtreatment of prisoners of war, and of other members of the armed forces of the countries with whom Germany was at war, and of persons on the high seas'. ${ }^{74}$

The IMT judgment, under the heading of 'War Crimes and Crimes against Humanity', held that '[p]risoners of war were ill-treated and tortured and murdered, not only in defiance of the well-established rules of international law, but in complete disregard of the elementary dictates of humanity. ${ }^{75}$ The tribunal repeatedly dealt with war crimes and crimes against humanity under the same heading when assessing individual responsibility, convicting Keitel, ${ }^{76}$ Kaltenbrunner, ${ }^{77}$ and Speer ${ }^{78}$ of crimes against humanity as a result of acts against prisoners of wars. These various findings show that members of opposition armed forces were considered victims of crimes against humanity and thereby part of a 'civilian population'.

\footnotetext{
${ }^{72}$ UNWCC History (n 70) 202.

${ }^{73}$ Indictment of the Nuremberg International Military Tribunal (1947) vol I, 65.

${ }^{74} \mathrm{Ibid}$., 52. See also, 77 where the indictment summarises the participation of the accused Keitel, alleging his participation in "War Crimes and Crimes against Humanity involved in the ill-treatment of prisoners of war and of the civilian population of occupied territories."

${ }^{75}$ Judgment of the International Military Tribunal (14 November 1945 - 1 October 1946) vol I, 226.

${ }^{76}$ Ibid., 289.

77 Ibid., 292.

${ }^{78}$ Ibid., 332. See also, for the same approach to other accused, Von Ribbentrop, 287; Bormann, 340-341.
} 
Further, the UNWCC's work shows how the term 'any civilian population' was considered to refer to a state's 'own subjects', ${ }^{79}$ categorising crimes against humanity as 'offences committed on the territory of Germany and her Allies against their own nationals', ${ }^{80}$ and 'crimes committed against any person without regard to nationality, stateless persons included, because of race, nationality, religious or political belief' ${ }^{81}$ Arguably, the marked absence of the term "civilian" when describing those who made up a 'civilian population' indicates a broader conception than merely non-combatants.

Jurisprudence echoes this. For example, the Alstotter et al. judgment held that crimes against humanity related to 'crimes committed against German nationals' ${ }^{82}$ The 'notes on the case' contained in the contemporaneous report on Alstotter et al. further indicates the broad interpretation of crimes against humanity being drawn on, stating:

that the possible victims of crimes against humanity form a wider group than the possible victims of war crimes. The latter category comprises broadly speaking the nationals or armed forces of belligerent countries or inhabitants of territories occupied after conquest against whom offences are committed by enemy nationals as long as peace has not been declared. Crimes against humanity on the other hand may be committed also by German nationals against other German nationals or any stateless persons. ${ }^{83}$

The use of the terms 'subject', 'national', and 'person' in these various texts when referring to those who comprised 'any civilian population' is significant. These terms - which would include members of the armed forces - are particularly important when considering the need to ensure that acts against belligerent forces, legal under international humanitarian law, would not be criminalised under crimes against humanity - which could have been achieved by simply using the word 'civilian'. These sources, then, strongly suggest that post-World War II legal documents did not intend to exclude conduct against one's own armed forces from the concept of crimes against humanity.

\footnotetext{
${ }^{79}$ UNWCC History (n 70) 189 (emphasis added).

${ }^{80}$ Ibid., 35 (emphasis added). See also, 35-36.

${ }^{81}$ UNWCC, 'Scope of the Retributive Actions of the United Nations. Conclusions proposed by the Drafting Committee' (12 May 1944) III/5, para. 3 (emphasis added).

${ }^{82}$ Trials of War Criminal Before the Nuremberg Military Tribunals, 'The Justice Case' (October 1946April 1949) vol III, 47 (emphasis added).

${ }^{83}$ UNWCC, 'Law Reports of Trials of War Criminals' (UNWCC 1948) vol VI, 79 (emphasis added).
} 
The ICIJ did not delve in detail into these aspects of interpreting post-World War II sources, other than determining that the definition contained in Article 2(c) of Control Council Law No. 10 (CCL10) - which did not require a nexus to armed conflict for crimes against humanity - was operative, rather than the earlier Article 6(c) of the Nuremberg Charter, in which crimes against humanity were first propounded. ${ }^{84}$

(ii) Murder and persecution type crimes against humanity

The ICIJ rejected the relevance of the post-World War II definition of crimes against humanity and its two two-fold 'murder-type' and 'persecution-type' offences, the latter of which (due to Article 6 of the Nuremberg Charter and Article 2(1) of CCL10) did not need to be directed against a civilian population. ${ }^{85}$ This was because Article 5 of the ECCC Law expressly requires 'that persecution-type [crimes against humanity] be committed in the context of a widespread or systematic attack against any civilian population'. ${ }^{86}$ This is a rather hasty dismissal of the issue, however. The ICIJ was required to interpret the state of customary international law in relation to crimes against humanity as of $1975 .{ }^{87}$ Therefore, the question of whether crimes against humanity included crimes of persecution committed against soldiers - by dint of the absence of a reference to a civilian population in the relevant texts - is very important. Significantly, the distinction between 'murder-type' and 'persecution-type' crimes against humanity endured beyond the Charters of the IMT, International Military Tribunal for the Far East, and Control Council Law 10, and is also found in the 1950 Nuremberg Principles, the 1954 Draft Code of Offences Against Peace and Security, and the 1968 Convention on the Non-Applicability of Statutes of Limitations on International Crimes. Moreover, the ECCC's Supreme Court Chamber acknowledged this twin-track definition of crimes against humanity in the Case 001 Appeal Judgment, although it did not take a position on its customary law status. ${ }^{88}$

Persecution is an umbrella crime, in that it must be committed through other act(s). Consequently, if it is accepted that customary international law did not require the crime of persecution to be committed against a civilian population, then likewise the proposition that murder-type crimes against humanity committed against members of

\footnotetext{
${ }^{84}$ ICIJ Crimes Against Humanity Decision (n 7) para. 31.

${ }^{85}$ Ibid., para. 33.

${ }^{86}$ Ibid., para. 34.

${ }^{87}$ Ibid., para. 2.

${ }^{88}$ Case 001 Appeal Judgment (n 64) para. 233.
} 
the armed forces were punishable under international criminal law so long as they were perpetrated with a discriminatory intent is equally valid. This would bear on the question of how customary international law defined a civilian population during the relevant period. This argument goes directly to the principle of legality, as if customary international law in 1975 permitted the punishment of persecution against one's own armed forces, then the prohibition against committing other crimes against humanity that could be characterised as persecutory acts against a party's own armed forces was undoubtedly foreseeable. The ICIJ's unwillingness to engage this point was, perhaps, a missed opportunity to bolster the decision's reasoning. ${ }^{89}$

Instead, the ICIJ relied on the Alstotter and Ohlendorf judgments, ${ }^{90}$ as well as on $P$ and Others, the H Case and the $R$ Case (three Supreme Court of British Occupied Zones in Germany cases), to focus on the nature of the attacks rather than the status of the victims. ${ }^{91}$ On the basis of these five cases, the ICIJ concluded that, according to postWorld War II jurisprudence, the elements of crimes against humanity were satisfied when individual crimes were connected to a system of large-scale human rights abuses not perpetrated during combat operations, without further enquiry into status of the persons affected. ${ }^{92}$

The ICIJ considered there to be no further 'official definition' of crimes against humanity subsequent to the post-World War II jurisprudence until the establishment of the ad hoc tribunals of the 1990s. ${ }^{93}$ The ICIJ pointed to the authoritative definition of 'civilian' in the Blaškić Appeal Judgment, which relied on Article 50(1) of Additional Protocol I when holding that armed forces, militias, etc. cannot be considered as civilians for the purposes of crimes against humanity. ${ }^{94}$ The ICIJ noted that because Article 50(1) relates to the principle of distinction in international humanitarian law, and so presupposes the existence of an armed conflict, ${ }^{95}$ it did not assist determining the meaning of the term 'civilian' in relation to crimes against humanity not occurring in an ongoing armed conflict. ${ }^{96}$ The ICIJ also reviewed jurisprudence from the ad hoc

\footnotetext{
${ }^{89}$ Jørgensen (n 62) 224.

${ }^{90}$ ICIJ Crimes Against Humanity Decision (n 7) para. 38.

${ }^{91}$ Ibid., paras 39-42.

${ }^{92}$ Ibid., para. 43. See also, para. 32.

${ }^{93}$ Ibid., para. 32.

${ }^{94}$ Blaškić Appeal Judgement (n 61), para. 113.

${ }^{95}$ ICIJ Crimes Against Humanity Decision (n 7) paras 51-52.

${ }^{96}$ Ibid., para. 52.
} 
tribunals that followed an alternative path to that laid down in Blaškić Appeal Judgment, and that focused on 'the specific situation of the victims at the moment the crimes were committed, rather than their formal status'. ${ }^{97}$

Ultimately, the ICIJ decided that, because this international humanitarian lawinfluenced interpretation of 'civilian' was only accepted after the time relevant to the ECCC's jurisdiction, it would not violate the principle of legality if it were not followed..$^{98}$ Nevertheless, the ICIJ analysed the jurisprudence of the ad hoc tribunals at length, ${ }^{99}$ despite his role being to determine the customary definition of 'any civilian population' in 1975. Consequently, the ICIJ's conclusion that 'the specific situation criterion, rather than the IHL criterion [...] must be applied' is striking, ${ }^{100}$ given that both of these criteria for defining 'civilian population' come from the ad hoc tribunals' jurisprudence, and not from the relevant state practice or opinio juris prior to 1975 .

As mentioned above, because of the unique context in which this decision arose, it was not subject to further litigation on appeal. Notably, the ICIJ decision is at odds with ECCC jurisprudence. In Case 002/01, the Trial Chamber found that there was no customary definition of 'civilian' in $1975,{ }^{101}$ and adopted what it considered the ordinary definition of the term - consistent with the Blaškić Appeal Judgment. ${ }^{102}$ This was subsequently affirmed by the Supreme Court Chamber. ${ }^{103}$ Thus, the ICIJ's decision effectively seeks to alter the applicable definition of crimes against humanity before the Court., without directly engaging with the issue of following existing ECCC jurisprudence,

\section{Parallel Development of Protection? Conclusion on the ICC and the ECCC's}

\section{Approach}

The preceding analysis showed that both the ICC and the ECCC used creative interpretation when deciding that crimes committed by a state or armed group against members of their own armed forces fell within their respective jurisdictions as war crimes or crimes against humanity. Three Chambers of the ICC have come to two

\footnotetext{
${ }^{97}$ Ibid., para. 49. See also, para. 50.

${ }^{98}$ Ibid., para. 59.

${ }^{99}$ Ibid., paras 47-54.

${ }^{100}$ Ibid., para. 55.

${ }^{101}$ Case 002/01, Judgment, 002/19-09-2007/ECCC/TC, 7 August 2014, para. 185.

${ }^{102}$ Ibid., para. 186.

${ }^{103}$ Case 002/01 Appeal Judgment (n 61), para. 738, citing Blaškić Appeal Judgment (n 61) paras 110113.
} 
different conclusions, but none have tackled the main weaknesses of their position. Likewise, the ICIJ at the ECCC arrived at a conclusion regarding the state of customary international law in 1975 with very little reference to the building blocks of custom and was seemingly guided by events after the relevant time period.

As such, the precedential value of the ICC and ECCC decisions may be questionable. The anomalies and gaps in their reasoning may lead one to conclude that the decisions were not fully justified, and that members of armed groups or state armed forces fall into a lacuna of international criminal law, where grave crimes committed against them by their colleagues or superiors fall outside the jurisdiction of international courts. While such acts could still technically be prosecuted under the domestic criminal law of the state in which they were committed, this would, of course, depend on whether there was the will to do so (likely to be a particular issue in the case of a state targeting its own forces) and the capacity of the justice system to deliver accountability. The fundamental importance of the question therefore remains. Consequently, the following section examines the parameters of the legal regimes of international humanitarian law and crimes against humanity to assess whether there are situations where intra-armed forces crimes could be prosecuted as either war crimes or crimes against humanity and if the conclusions reached at the ICC and ECCC can therefore be supported.

\section{Towards Accountability for Crimes Against Members of Own Armed Forces?}

We suggest that there is an overarching approach which is based on an assessment of whether the victim at the operative time was protected under international law. We argue, first, that the concepts of hors de combat (for non-international armed conflict) and 'allegiance' (in international armed conflict) allow for situations in which individuals are protected from mistreatment by their own forces in the context of war crimes, and second, that the concept of 'lawful target' may provide for protection of members of armed forces from their own side in the context of crimes against humanity, whether in peacetime or wartime.

This approach could be perceived as judicial overreach into domestic sovereign matters, but this is allayed by at least three considerations. First, international criminal law has an inherent gravity threshold before a course of conduct becomes subject to potential individual responsibility. Taking the Rome Statute as an example, there is a requirement that in order to be a crime against humanity an attack must be 'widespread 
or systematic'; and that war crimes be committed 'as part of a plan or policy or a part of a large-scale commission of such crimes'. ${ }^{104}$ In order to be prosecuted as a crime against humanity or war crime, the relevant chapeau elements must be satisfied. Therefore, an isolated incident by one soldier against a fellow-soldier will not constitute a war crime unless a nexus to the armed conflict can be established. ${ }^{105}$ In the case of Ntaganda, the fact that the victims were recruited to UPC/FPLC forces in order to increase its military strength in the context of the Ituri conflict, and that the crimes in question took place whilst the victims were either in training camps or deployed on military operations, was important to the establishment of that nexus. ${ }^{106}$

Second, in any domestic judicial proceedings, the underlying act(s) would already be legally prohibited conduct, i.e. the rape of one's own soldier is still rape whether characterised as a war crime or not. Third, for almost a century international law has been slowly paring back the traditional notion that how a state treats persons within its borders is solely a matter for the state in question. ${ }^{107}$ Notably, the crime of genocide protects all national, ethnic, racial and religious groups without any distinction on the basis of the individual victim's status or role. To suggest that members of armed groups or forces are automatically excluded from the scope of war crimes or crimes against humanity where the perpetrator is their own state or armed group would create an artificial bifurcation in the application of international criminal law. Therefore, whilst understanding that states will normally oppose interpretations of international law that seem to create additional obligations or places individuals from that state at risk of legal jeopardy, the following analysis is firmly rooted in existing international regimes of accountability governing inter- and intra- state relations.

\section{A. Prosecuting violations against members of the same armed forces as war crimes}

The Ntaganda case was not the first to examine whether mistreatment of members of the same armed forces could constitute war crimes. Both the SCSL and the ICTY have

\footnotetext{
${ }^{104}$ Rome Statute of the International Criminal Court (adopted 17 July 1998, entered into force 1 July 2002) 2187 UNTS 90, art 8(1).

${ }^{105}$ While the Ntaganda Trial Judgment did not re-visit the question of whether members of the same armed force could be victims of war crimes, given that the issue had been comprehensively addressed in the preceding case law outlined at $\mathrm{n} 5$ above, it did emphasise that a nexus must be established with the armed conflict in question for conduct to qualify as a war crime: Situation in the DRC: Prosecutor v. Ntaganda, Judgment, Case No. ICC-01/04-01/06-2359, 8 July 2019, paras. 731-733.

106 Ibid., paras 983-986.

${ }^{107}$ See, e.g. UNGA Res 60/1 (24 October 2005) UN Doc A/RES/60/1, paras 138-140; UNSC Res 1674 (28 April 2006) UN Doc S/RES/1674.
} 
addressed this question, although perhaps somewhat more tangentially than by the ICC in Ntaganda. In the RUF case, which dealt with a non-international armed conflict, the SCSL's Trial Chamber held in 2009 that 'the killing of a member of an armed group by another member of the same group does not constitute a war crime'. ${ }^{108}$ Even where the victim was the member of a distinct but allied armed group (as in the $R U F$ case $^{109}$ ), the SCSL Trial Chamber reiterated that violence against soldiers from non-opposing sides of a conflict was solely the purview of domestic criminal law and human rights law. ${ }^{110}$ The SCSL Trial Chamber concluded 'that the law of armed conflict does not protect members of armed groups from acts of violence directed against them by their own forces', ${ }^{111}$ and that an armed group cannot, for example, hold its own members as prisoners of war. ${ }^{112}$

Despite the SCSL Trial Chamber's finding, the Geneva Conventions do not explicitly limit protection to enemy forces. A number of provisions speak generally about members of 'a Party to the conflict', without saying that such members are only protected vis-à-vis enemy forces. ${ }^{113}$ Similarly, Article 10 of Additional Protocol I refers to the protection of the 'wounded, sick, and shipwrecked, to whichever Party they belong'. 114

The ICTY Appeals Chamber took a very different approach to that of the SCSL in its 2005 Kvočka judgment, in which it concluded that detention and mistreatment of an armed group's own members was an example of when the law of armed conflict would reasonably be expected to protect those individuals. ${ }^{115}$ The Trial Chamber had convicted one of the co-accused, Žigić, of, inter alia, a war crime for the murder of

\footnotetext{
${ }^{108}$ Prosecutorv. Sesay, Kallon and Gbao, Judgment, Case No. SCSL-04-15-T, 2 March 2009, para. 1455 ('RUF Judgment').

${ }^{109}$ Ibid., paras 1451 and 1457. Some of the victims were combatants affiliated to the Armed Forces Revolutionary Council (AFRC), who fought alongside the Revolutionary United Front (RUF) in Sierra Leone's civil war.

${ }^{110} \mathrm{Ibid}$., para. 1453, adding 'In our view, a different approach would constitute an inappropriate reconceptualisation of a fundamental principle of international humanitarian law'.

${ }^{111}$ Ibid., para. 1451.

112 Ibid., para. 1452

${ }^{113}$ E.g. Articles 13(1) and (2) of Geneva Conventions I and II.

114 Article 10, Additional Protocol I (emphasis added).

${ }^{115}$ Prosecutor v. Kvočka, Judgment, Case No. IT-98-30/1-A, 28 February 2005. See further, Jann K. Kleffner, 'Friend or Foe? On the Protective Reach of the Law of Armed Conflict', in Marielle Matthee, Brigit Toebes and Marcel Brus (eds), Armed Conflict and International Law: In Search of the Human Face (The Hague: T.M.C. Asser Press, 2013), 285, 299-300.
} 
Drago Tokmadžić in the Omarska camp. ${ }^{116}$ On appeal, Žigić contended that Tokmadžić, a half-Serbian, half-Croatian former policeman who had declared loyalty to the Serbian authorities and who had transferred detainees to a Serbian camp, thus showing his active role on behalf of the Serb armed forces, ${ }^{117}$ could not be considered a prisoner of war. ${ }^{118}$ The Prosecution argued that, in light of the nexus between the armed conflict, the camps, and the mistreatment, Tokmadžić's murder constituted a war crime. ${ }^{119}$ The Appeals Chamber concurred, finding that, because Tokmadžić 'was detained in the camp, he belonged to the group of persons protected by the Common Article 3 of the Geneva Conventions.' ${ }^{120}$ This approach supports the interpretation taken by the ICC Pre-Trial Chamber in Ntaganda, which focused on the victims' lack of direct participation in hostilities at the time of their victimisation rather than to which side of the conflict they belonged. ${ }^{121}$

\section{i. The Range of Protection in Non-International Armed Conflicts}

In non-international armed conflicts, the beneficiaries of Common Article 3 include not only those who have never taken part in hostilities, but also those fighters placed hors de combat by 'sickness, wounds, detention, or any other cause.' ${ }^{122}$ Article 4 of AP II, like Common Article 3, draws no distinction between those taking no active part in hostilities who are civilians and those who are former combatants, nor is there any requirement that such persons be in the hands of an enemy party. Similarly, Article 7 of AP II, which protects the wounded, sick and shipwrecked, applies regardless of whether they have taken part in hostilities. Article 7(2) clarifies that no difference in treatment should apply for any reason other than medical grounds. Thus, there is no explicit limitation in either Common Article 3 or Additional Protocol II that suggests their protections extend only to those in the hands of an enemy. Indeed, the recruitment and use of child soldiers, which is prohibited in both international and non-international

\footnotetext{
116 Prosecutor v. Kvočka, Judgment, Case No. IT-98-30/1-T, 2 November 2001, para. 691.

${ }^{117}$ Kvočka Appeals Judgment (n 115), paras 457-458.

${ }^{118}$ Kvočka Appeals Judgment (n 115), para. 560.

${ }^{119} I d$. The Prosecution apparently did not focus on the fact of the detainee's (former) allegiance to the detaining authorities.

${ }^{120}$ Kvočka Appeals Judgment (n 115), para. 561.

${ }^{121}$ Ntaganda Pre-Trial Chamber decision (n 5).

${ }^{122}$ Common Article 3 (emphasis added).
} 
armed conflicts, is by its very nature a violation committed against members of the same armed group. ${ }^{123}$

The sole restriction on the application of Common Article 3 (and, therefore, , the war crimes derived from that provision) is that the beneficiary of its protection must be taking no active part in hostilities. ${ }^{124}$ This is true also for AP II, which, pursuant to Article 1(1) 'develops and supplements' Common Article 3. AP II limits protection to those not taking, or no longer taking active, part in hostilities but does so without distinction as to which side of the conflict they originate from. ${ }^{125}$ As Common Article 3 binds 'each Party to the conflict' to treat those persons taking no active part in hostilities humanely, there is no suggestion that the provision protects only those noncombatants in the hands of an adverse party. It will, of course, usually be the case that those seeking to benefit from the protection of Common Article 3 will be those who have never taken part in hostilities or who have ceased to to do so and are under the control of the State or armed group to which they bear no allegiance. Nevertheless, nothing in the wording of the provision limits its protection to only one side.

Apart from being supported by a literal interpretation, a teleological interpretation also suggests a broader understanding according to which Common Article 3 and Additional Protocol II apply to members of the same armed forces when no longer participating in hostilities. ${ }^{126}$ Pictet's original Commentaries to the Geneva Conventions emphasise the humanitarian principles underpinning the Conventions throughout. In his commentary to the Geneva Convention I, Pictet noted the 'universally recognised principle' expressed in the Geneva Conventions that 'any wounded or sick person whatever... is entitled to respect and humane treatment'. ${ }^{127}$ The Pictet commentary to Geneva Convention III noted that the principle of 'respect for human personality' is the

\footnotetext{
${ }^{123}$ Article 77(2), Additional Protocol I; Article 4(3)(c), Additional Protocol II. See further Rodenhauser (n 22),

${ }^{124}$ Jann Kleffner, 'The Beneficiaries of the Rights Stemming from Common Article 3', in Clapham et al (n 1), 433, 436.

${ }^{125}$ Article 4(1), Additional Protocol II.

${ }^{126} \mathrm{Cf}$. Newton (n 44), 523-524, stating that states' primary concerns at the time of drafting were to preserve the sovereignty of the state and to ensure that insurgents did not benefit from too many protections. There appears to be nothing in the drafting of the Conventions on excluding members of the same armed forces; states were more concerned with the possibility that they might have to recognise armed groups.

${ }^{127}$ Jean Pictet, Commentary on the Geneva Conventions of August 12 1949: Volume I (Geneva: ICRC, 1952), 145
} 
foundation of the Conventions. ${ }^{128}$ This principle, in Pictet's words, is 'concerned with people as human beings, without regard to their uniform, their allegiance, their race or their beliefs, without regard even to any obligations which the authority on which they depended might have assumed in their name or in their behalf.' 129

Further justification can be found in the non-discrimination clauses of Common Article 3 and Additional Protocol II. ${ }^{130}$ These clauses make it clear that the protections apply to all persons not directly participating in hostilities 'without any adverse distinction founded on race, colour, religion or faith, sex, birth or wealth, or any other similar criteria.' ${ }^{131}$ Pictet argued that the drafters' inclusion of the non-discrimination clause in the First Geneva Convention was a recognition of the principle 'that when faced with suffering, no distinction should be drawn between brothers-in-arms, the enemy and allies. ${ }^{132}$ Of course, the assumption here was that 'brothers-in-arms' or 'allies' would normally be treated more favourably than enemy fighters, but the non-discrimination principle applies to all persons hors de combat, regardless of their allegiance.

\section{ii. The Protection of Those Hors de Combat in Non-International Armed Conflicts}

When determining whether a member of an armed group is in a specific situation requiring protection, the question of whether they are hors de combat or no longer participating in hostilities is clearly central. The ICRC's Customary IHL Rule 47 defines three categories of persons hors de combat: those in the power of an adverse party; those who are wounded, shipwrecked, sick or unconscious; and those who have clearly expressed an intention to surrender. ${ }^{133}$ In its commentary, the ICRC notes that Article 41(2) of AP I establishes the principle that those in the hands of an adverse party are to be considered hors de combat, a principle it finds to be implicit to both Common Article 3 and Article 4 of AP II. The basic premise of this principle is that individuals

\footnotetext{
128 Jean de Preux, Commentary on the Geneva Conventions of August 12 1949: Volume III (Geneva: ICRC, 1960), 28

${ }^{129} \mathrm{Id}$.

${ }^{130}$ Article 2, Additional Protocol II; Common Article 3. See further Kleffner (n 124), 436; Kleffner (n115), 300.

${ }^{131}$ Common Article 3. Article 2, Additional Protocol II has a broader list of impermissible adverse distinctions, stating that the Protocol 'shall be applied without any adverse distinction founded on race, colour, sex, language, religion or belief, political or other opinion, national or social origin, wealth, birth or other status, or on any other similar criteria.'

132 Pictet (n 127), 55.

133 Commentary to ICRC Customary IHL Study, Rule 47, available online at https://hhldatabases.icrc.org/customary-ihl/eng/docs/v1_rul_rule47 (stating that this is a customary rule of IHL applicable in both international and non-international armed conflicts).
} 
are presumed to benefit from the protection of their own party, but as soon as they fall into the hands of a hostile party, they require the protection of the law of armed conflict. On this basis, the fighter whose original armed group has turned hostile could be considered as in the hands of 'an adverse party' and thus hors de combat, and so a beneficiary of the protections of the law relating to non-international armed conflicts. ${ }^{134}$ In the $R U F$ judgment, the SCSL described the AFRC fighter who had been detained for not carrying an RUF travel pass ${ }^{135}$ and later killed by the RUF as 'an hors de combat member of the AFRC [who were fighting alongside the RUF]'. ${ }^{136}$ Despite its conclusion that the law of armed conflict did not protect this individual from acts of violence committed against him by his own forces, ${ }^{137}$ this finding explicitly recognised that individuals can be considered hors de combat, regardless of which party to the conflict has detained them. ${ }^{138}$ The SCSL Trial Chamber's judgment neglected to elaborate on why Common Article 3 could not apply where an individual had been placed hors de combat by their own side. Instead, it limited its analysis to generalised remarks on the intention of states in formulating the law of armed conflict. ${ }^{139}$ This was an unfortunate oversight, given that Common Article 3 explicitly protects those hors de combat without exception. It could have been argued that the logic of protecting those placed hors de combat derives from the recognition that they no longer pose a threat to the opposing armed forces, ${ }^{140}$ and therefore are protected only from attacks by those enemy armed forces. On the other hand, it is equally clear that those placed hors de combat by their own armed group equally pose no threat to the group of which they are a member, and thus are entitled to the same protection.

The conclusion that the only bar to the operation of Common Article 3 is whether the individual is no longer participating in hostilities most closely mirrors the analysis of the Pre-Trial Chamber in Ntaganda. As discussed above, this approach raises questions concerning the applicability of the continuous combat function principle, under which

\footnotetext{
${ }^{134}$ We make a similar argument in relation to international armed conflicts in sub-section iii below.

${ }^{135}$ RUF Judgment (n 108), para. 1389.

${ }^{136}$ Ibid., para. 1451.

${ }^{137}$ Ibid.

138 'Any other cause', for these purposes, could include incidents of the commission of crimes against an individual by members of their own forces, because during such time they would not be in a position to actively participate in hostilities.

${ }^{139}$ RUF Judgment (n 108), paras 1451-1454.

${ }^{140}$ Russell Buchan, 'The Rule of Surrender in International Humanitarian Law' (2018) 51 Israel Law $\operatorname{Rev} 3$.
} 
the individual whose continuous function it is to take a direct part in hostilities loses his or her protection from direct attack for the duration of their membership of the armed force. ${ }^{141}$ However, while those who carry out a continuous combat function may indeed be legitimate targets of a direct physical attack by the adversary, ${ }^{142}$ the idea that direct participation in hostilities or the bearing of a continuous combat function places combatants completely outside the scope of international humanitarian law's protection is misconceived. ${ }^{143}$ While participation in hostilities renders the fighter a legitimate target of direct attack by the adversary, the definitive issue is whether they are hors de combat in the hands of a party, not whether they are a fighter. Moreover, 'the right of the parties to an armed conflict to choose methods or means of warfare is not unlimited'. ${ }^{144}$ Therefore, it does not follow from the fact that individuals can be lawfully targeted that any party to the conflict has carte blanche to mistreat them. ${ }^{145} \mathrm{It}$ would seem illogical to suggest that those carrying out a continuous combat function may legitimately be subjected to rape or torture. The continuous combat function is a principle designed to assist forces in making distinction decisions on who can be killed or injured on the battlefield, and restrictions on the means and methods employed still apply when conducting such attacks.

As mentioned in Section 2.A.ii above, the specific context of the Ntaganda Pre-Trial Chamber decision, where it was suggested that child soldiers do not lose their protection as civilians, ${ }^{146}$ gives rise to a question concerning the reach of the notion of direct participation in hostilities: would a broader reading of the concept would preclude victims from also being recognised as victims of the war crime of conscripting and enlisting children under the age of 15 to actively participate in hostilities. The Lubanga Trial Chamber overcame this obstacle by reading the concept of 'active participation in hostilities' as being broader than that of 'direct participation in hostilities', with the former encompassing roles that support the armed group. ${ }^{147}$ By contrast, the ICRC's

\footnotetext{
${ }^{141} \mathrm{ICRC}$ (n 16), 28.

${ }^{142}$ Nils Melzer, 'The Principle of Distinction Between Civilians and Combatants', in Andrew Clapham and Paola Gaeta (eds), The Oxford Handbook of International Law in Armed Conflict (Oxford: OUP, 2014), 296, 312

${ }^{143}$ Jelena Pejic, 'The protective scope of Common Article 3: more than meets the eye' (2011) 93 Int'l Rev of the Red Cross 881, 1, 36.

${ }^{144}$ Article 35, Additional Protocol I.

145 Rodenhauser (n 22), 186-187.

${ }^{146}$ Ntaganda Pre-Trial Chamber decision (n 5), para. 78.

${ }^{147}$ Lubanga Judgment (n 20), para. 628.
} 
interpretative guidance suggested that 'direct' and 'active' participation in hostilities are interchangeable concepts under international humanitarian law. ${ }^{148}$ The Lubanga Appeals Chamber noted the different purposes of the wording in international humanitarian law (when it is used for distinction assessments) vis-à-vis international criminal law (where the purpose is criminalising recruitment of child soldiers). ${ }^{149} \mathrm{On}$ that basis, it upheld a reading of 'active participation in hostilities' that was broader than that of 'direct participation in hostilities' for the purposes of protecting children from recruitment into armed groups. It is likely that future cases before the ICC would take a similarly broad view of 'active participation' in order to permit a wide range of child members of armed groups to be considered victims of the war crime of recruiting or using child soldiers.

Overall, then, it is clear that the most crucial consideration in determining whether a member of an armed group can be considered a victim of particular war crimes ${ }^{150}$ in the context of a non-international armed conflict, provided that the mistreatment fulfils the elements of the relevant offences, is whether they were directly participating in hostilities at the time of their victimisation such that they are characterised as hors de combat. ${ }^{151}$

\section{iii. Protection Under the Concept of Allegiance in International Armed Conflict}

Turning to war crimes in the context of international armed conflicts, similar arguments can be made, based on the specific situation of an individual victim and centring on the concepts of allegiance, hors de combat, and what it means to be 'in the hands of an adverse party' for the purposes of protection under the law of armed conflict. While the law in relation to non-international armed conflicts offers protection to all those not actively participating in hostilities, the law relating to international armed conflicts

\footnotetext{
${ }^{148}$ ICRC (n 16), 43-44.

${ }^{149}$ Prosecutor v. Lubanga, Judgment on the appeal of Mr Thomas Lubanga Dyilo against his conviction, Case No. ICC-01/04-01/06-3121, 1 December 2014, paras 323-328.

${ }^{150}$ The so-called 'Geneva Law offences', or offences against persons in the hands of a party to an armed conflict: Cottier (n 27), 319-321.

${ }^{151}$ Under the ICC Statute, the following war crimes are committed against individuals in noninternational armed conflicts: all of the acts enumerated under Article 8(2)(c) and Article 8(2)(e).
} 
distinguishes between 'combatants', including those combatants entitled to protection as a consequence of being hors de combat, and 'civilians'. ${ }^{152}$

The case law of the ICTY has recognised that members of the same armed forces can be considered 'protected persons' under the Fourth Geneva Convention in an international armed conflict. This Convention focuses on whether civilians are in the hands of a Party to the conflict or Occupying Power of which they are not nationals ${ }^{153}$ for the purposes of protection, but it is increasingly recognised that 'nationality', in the formal sense of citizenship, should not be the sole determinant for protection under the Convention. ${ }^{154}$ In Tadić, the Appeals Chamber noted that the drafting history of the Convention revealed a concern with whether the national was able to benefit from the diplomatic protection of a state. ${ }^{155}$ Thus it was important to construe nationality in the sense of allegiance to a Party rather than formal bonds. ${ }^{156}$ This allegiance approach was followed by the Delalić et al Appeals Chamber, which found that 'protected persons' may encompass victims of the same nationality as the perpetrator if the perpetrator acts on behalf of a state that does not offer the victim diplomatic protection or to which the victim bears no allegiance. ${ }^{157}$

Most recently, the question arose in the Prlić case as to whether Muslim members of the Croatian Defence Council (HVO) who were later detained by the HVO could be considered prisoners of war protected by the Third Geneva Convention. ${ }^{158}$ On a literal reading of the Convention, it would appear that such detainees could not be regarded as having 'fallen into the power of the enemy', ${ }^{159}$ since they were members of the armed forces which detained them. ${ }^{160}$ However, the Trial Chamber found that the

\footnotetext{
${ }^{152}$ Article 50(1) of Additional Protocol I defines civilians as persons who do not belong to one of the categories of persons referred to in Article 4(A)(1), (2), (3), and (6) of the Third Geneva Convention. See also Additional Protocol I, Article 43.

${ }^{153}$ Article 4(1), Geneva Convention I.

${ }^{154}$ Kim Rubenstein, 'Rethinking Nationality in International Humanitarian Law', in Ustinia Dolgopol and Judith Gardam (eds.), The Challenge of Conflict: International Law Responds (Leiden: Brill, 2006) 89,90 .

${ }_{155}$ Prosecutor v. Tadić, Judgment, Case No. IT-94-1-A, 15 July 1999, paras 164-165; 168.

${ }^{156}$ Ibid., para. 166.

${ }^{157}$ Prosecutor v. Delalić et al, Judgment, Case No. IT-96-21-A, 20 February 2001, para. 418; see also Prosecutor v. Kordić and Čerkez, Judgment, Case No. IT-95-14/2-A, 17 December 2004, para. 329; Prosecutor v. Lubanga, Decision on the Confirmation of the Charges, Case No. ICC-01/04-01/06-803, 7 February 2007, para. 278.

${ }^{158}$ Prosecutor v. Prlić et al, Judgment, Case No. IT-04-74-A, 29 November 2017, para. 348.

${ }^{159}$ Article 4(A), Geneva Convention III.

${ }^{160}$ Prosecutor v. Prlić et al, Judgment, Case No. IT-04-74-T, 29 May 2013, paras 603-605.
} 
Muslim HVO detainees were protected under the Fourth Geneva Convention as civilians, on the basis of an allegiance test. ${ }^{161}$ It considered that from at least 30 June 1993, the HVO deemed its Muslim members to be loyal to the Army of Bosnia and Herzegovina. ${ }^{162}$ As such, the HVO Muslim members detained by the HVO after that date had fallen into the hands of the enemy party and were thus protected persons under the Fourth Geneva Convention. ${ }^{163}$ On appeal, the Defence argued that the Fourth Geneva Convention only protects civilians, and detained HVO combatants could not be considered civilians for its purposes. ${ }^{164}$ The defence also argued that how a state treats its own armed forces is solely a matter for domestic law. ${ }^{165}$ As regards the first objection, the Appeal Judgment, handed down in 2017, found that Geneva Convention IV, whilst primarily concerned with the protection of civilians, protects all persons who fall into the hands of an enemy party to the conflict. ${ }^{166}$ Applying the allegiance criterion as developed in the ICTY's earlier jurisprudence, ${ }^{167}$ the Chamber concluded that the Trial Chamber was correct in determining that the Muslim HVO detainees were protected under Geneva Convention IV, 'because they were in fact in enemy hands, and "[e]very person in enemy hands must have some status under international law [...]. There is no intermediate status; nobody in enemy hands can be outside the law." 168 As regards the argument that only national law was applicable to such conduct, the Appeals Chamber found that the legal authority for this proposition constituted 'non-Tribunal authorities', whereas the allegiance test constituted the Tribunal's established jurisprudence from which there was no good reason to depart. ${ }^{169}$

The Prlić Trial and Appeal judgments, therefore, demonstrated that if an individual, forcibly recruited or otherwise, is systematically subjected to criminal conduct by fellow members of the same armed forces in an international armed conflict, they should be considered to be 'in the hands of an enemy party' since they are not benefitting from the protection of that party and cannot be said to bear allegiance to the group that is mistreating them. Thus, when an individual is subjected to mistreatment

\footnotetext{
${ }^{161}$ Ibid., paras 606-608.

${ }^{162}$ Ibid., para. 610.

${ }^{163}$ Ibid., para. 611.

${ }^{164}$ Prlić Appeal Judgment (n 158), para. 349.

165 Ibid., para. 350.

166 Ibid., para. 354.

${ }^{167}$ Ibid., para. 358.

168 Ibid., para. 359.

${ }^{169}$ Ibid., para. 358.
} 
by his or her own armed group, the key question will be whether the pattern of mistreatment is such that he or she should be considered outside the scope of allegiance to that party. In these circumstances, and provided that the elements of the relevant offences are established, such mistreatment could be prosecuted as a war crime.

\section{B. Prosecuting violations against members of the same armed forces as crimes against humanity}

Perhaps surprisingly for something which is required for the attribution of individual criminal responsibility, there is a marked lack of clarity concerning who should be included under the umbrella terms 'civilian population' and 'civilian' in the context of crimes against humanity. The ICRC Commentary to Additional Protocol I acknowledged in 1987 that: '[i]n the course of history many definitions of the civilian population have been formulated, and everyone has an understanding of the meaning of this concept. However, all these definitions are lacking in precision [and] the categories of persons they cover has varied.' ${ }^{170}$ The Tadić trial judgment noted some ten years later that 'determining which individual of the targeted population qualify as civilians for purposes of crimes against humanity, is not [...] clear'. ${ }^{171}$ Despite twenty years of subsequent practice, the uncertainty persists.

Applying the 'specific situation' approach, we argue that a 'civilian' for the purposes of crimes against humanity should be interpreted as any individual who cannot lawfully be targeted for attack under international humanitarian law. Determining whether a person is a 'civilian' either in peacetime or during armed conflict - be it international or non-international armed conflict - should focus not on formal bonds but on the situation of the individual at the time of the commission of the alleged offence and an assessment of whether that person requires protection. ${ }^{172}$ Because they are designed to protect against large scale or systematic attacks on the fundamental rights of individuals, the status of a person targeted in such an attack does not affect the

\footnotetext{
${ }^{170}$ ICRC, Commentary on the Additional Protocols of 8 June 1977 to the Geneva Conventions of 12 Auagust 1949 (Martinus Nijhoff 1987) Additional Protocol I art 50, 610

${ }^{171}$ Prosecutor $v$ Tadić, Judgment, IT-94-I-T, 7 May 1997, para. 640.

${ }^{172}$ See, Blaškić Appeal Judgment (n 61) para. 111. Despite denying 'civilian status' to soldiers based on its interpretation of civilian through Additional Protocol I, the Appeals Chamber stated that when it is unclear as to whether a person is a civilian, that "the imperative "in case of doubt" is limited to the expected conduct of a member of the military.' Clearly during peacetime, the expected conduct of a soldier does not entail the undertaking of any action which would put that individual at risk of losing his/her protection under international law and opening themselves to legitimate targeting and killing.
} 
characterisation of the conduct as a crime against humanity. ${ }^{173}$ As held in the Kupreskic Trial Judgment: '[o]ne fails to see why only civilians and not also combatants should be protected by these rules (in particular by the rule prohibiting persecution), given that these rules may be held to possess a broader humanitarian scope and purpose than those prohibiting war crimes. ${ }^{174}$ Because everyone other than a member of a hostile armed force or group actively involved in fighting is in a specific situation requiring protection, ${ }^{175}$ soldiers targeted by their own fellow forces should also be considered 'civilians' for the purposes of crimes against humanity. Provisions denying such individuals protection under international humanitarian law should not be used to deny them protection from crimes against humanity. ${ }^{176}$

It is a mistake to unquestioningly transpose international humanitarian law definitions into the realm of crimes against humanity. In international humanitarian law the definitions of 'civilian' and 'civilian population' are driven by the principle of distinction, establishing the parameters for military action by indicating who may be lawfully targeted and killed. ${ }^{177}$ By contrast, crimes against humanity are focused on protecting the individual against arbitrary abuse of power, be it state or non-state power - military or otherwise. This is signified by the defining feature of crimes against humanity being an organized plan or policy to commit the relevant offences, ${ }^{178}$ which serves to exclude isolated or random acts against limited numbers of individuals from being so characterised. ${ }^{179}$ It therefore fits with the purpose of crimes against humanity to consider the need of a potential victim for protection when they are defenceless against a state or non-state organised force conducting an attack. ${ }^{180}$ Moreover, the concept of an 'attack' for the purposes of crimes against humanity is not the same as for war crimes, as it need not include the use of military force. ${ }^{181}$ Consequently, the

\footnotetext{
${ }^{173}$ Rosa Ana Fernández and Jaume Saura Estapà, 'Towards a Single and Comprehensive Notion of 'Civilian Population' in Crimes Against Humanity' (2016) 17 International Criminal Law Review 1, 24. ${ }^{174}$ Prosecutor v Kupreškić et al., Judgement, IT-95-16-T, 14 January 2000, para. 547.

${ }^{175}$ Christopher Hall and Kai Ambos, 'Article 7' in Otto Triffterer and Kai Ambos (eds.), Commentary on the Rome Statute of the International Criminal Court: Observers' Notes, Article by Article (Oxford: Hart/Beck, $3^{\text {rd }}$ edn., 2016),144, 174.

${ }^{176}$ Leila Nadya Sadat, 'Putting Peacetime First: Crimes Against Humanity and the Civilian Population Requirement' (2017) 31 Emory International law Journal 197, 212.

177 See, e.g., ICRC, 'Database of Customary International Humanitarian Law' (n 133), Rule 1.

178 David Luban 'A Theory of Crimes Against Humanity' (2004) 29 Yale J. Int'l L. 85, 98.

${ }_{179}$ Tadić Trial Judgment (n 171) para. 644, 648; Prosecutor v Kunarac et al., Judgement, IT-96-23/1-A, 12 June 2002, para. 90.

${ }^{180}$ Prosecutor v Šainović et al., Judgement, IT-05-87-T, 26 February 2009, para. 147.

${ }^{181}$ Ibid., para. 144.
} 
international humanitarian law definition of 'civilian' which encompasses notions such as 'subordination to a Party to the conflict, hors de combat and 'participation in hostilities' appears totally unsuitable in the absence of conflict. . Since crimes against humanity encompass violations of fundamental human rights, the definition of 'civilian population' should be focused on international human rights law. ${ }^{182}$

Because the initial conception of crimes against humanity at Nuremberg and its earliest modern affirmation at the ICTY expressly connected crimes against humanity to the commission of war crimes, it is hardly surprising that the definition of who is a 'civilian' and what is a 'civilian population' came to be viewed as being the same under both legal regimes. Perhaps equally predictably, these jurisprudential sources, specifically the ICTY, were relied upon by other international criminal tribunals -where a significant proportion of cases involved allegations of crimes against humanity committed in the context of an armed conflict. ${ }^{183}$ However, the armed conflict nexus of the ICTY Statute and the influence of its appellate jurisprudence on other courts have resulted in definitions of 'civilian' and 'civilian population' being applied in situations where there is no connection with war crimes without considering whether they were appropriate.. $^{184}$

Yet, while the ad hoc tribunals based their interpretation of the term 'civilian' in international humanitarian law, different chambers looked to different areas of IHL when defining 'civilian'. Trial judgments of the ICTY and ICTR, particularly early in their years, adopted a conception of civilian based on Common Article 3 of the Geneva Conventions, ${ }^{185}$ covering persons who had taken no part in hostilities, or were no longer doing so - including members of the armed forces who have laid down their arms and persons hors de combat. ${ }^{186}$

This early approach was exemplified in the 2000 Blaškić Trial Judgment, which held that 'the specific situation of the victim at the moment the crimes were committed,

\footnotetext{
182 Fernández and Estapà (n 173) 31.

183 See, Leila Nadya Sadat, 'Crimes Against Humanity in the Modern Age' (2013) 107 American Journal of International Law 334, 356.

${ }^{184}$ Sadat, Putting Peacetime First (n 176) 205.

${ }^{185}$ For the ICTR, the reliance on Common Article 3 was less surprising, given that its Statute does not contain any armed conflict requirement and that the court was addressing a situation of non-international armed conflict.

${ }^{186}$ Tadić Trial Judgment (n 171) paras 637-638; Prosecutor v Akayesu, Judgement, ICTR-96-4-T, 2 September 1998, para. 582.
} 
rather than his status, must be taken into account in determining his standing as a civilian', ${ }^{187}$ a position that was subsequently followed by various ICTY and ICTR chambers. ${ }^{188}$ As noted, the Blaškić Appeals Judgment took a different path, holding that the definition of 'civilian' and 'civilian population' in Article 50 of Additional Protocol I to the Geneva Conventions represented customary international law - a claim shorn of reasoning ${ }^{189}$ - and was applicable not only in international humanitarian law, but also for crimes against humanity. ${ }^{190}$ The Blaškić Appeals Chamber dismissed the Trial Chamber's consideration of the specific situation of the victim at the time the crimes were committed as 'misleading', ${ }^{191}$ because being a member of an armed group, irrespective of whether 'he is not armed or in combat at the time of the commission of crimes, does not accord him civilian status'. ${ }^{192}$ This judgment was relied on extensively in later jurisprudence by both the ICTY and other tribunals. ${ }^{193}$

But despite this authoritative Appeals Chamber precedent, many ICTY and ICTR Trial Chambers continued to employ the Common Article 3 approach. ${ }^{194}$ This continued reliance on a broader interpretation of 'civilian' may be attributed to the conceptual difficulty inherent in the Blaškić Appeals Chamber's focus on the formal status of those

${ }^{187}$ Prosecutor v Blaškić, Judgement, IT-95-14-T, 3 March 2000, para. 214.

188 Prosecutor v Naletilić \& Martinović, Judgement, IT-98-34-T, 31 March 2003, para. 235; Prosecutor $v$ Kajelijeli, Judgment and Sentence, ICTR-98-44A-T, 1 December 2003, paras 873-874; Prosecutor v Musema, Judgement and Sentence, ICTR-96-13-A, 27 January 2000, para. 207; Prosecutor v Rutaganda, Judgement and Sentence, ICTR-96-3-T, 6 December 1999, para. 72; Prosecutor $v$ Kamuhanda, Judgment, ICTR-95-54A-T, 22 January 2004, para. 667; Prosecutor v Bagilishema, Judgement, ICTR95-1A-T, 7 June 2001, para. 79

189 Sadat, Putting Peacetime First (n 176) 218.

${ }^{190}$ Blaškić Appeal Judgement (n 61), para. 110.

191 Though the ICTY Appeals Chamber disavowed the Blaškić Trial Judgment's reliance on the specific situation of an individual when assessing whether the person was a 'civilian', various Appeals Chambers have referred to the specific situation of the individual when assessing whether a 'civilian population' is just that. See, e.g., Prosecutor v Mrkšić et al., Judgement, IT-95-13/1-A, 5 May 2009, para. 30; Kunarac Appeal Judgment (n 179) para. 91; Blaškić Appeal Judgment (n 61), paras 113-115.

192 Blaškić Appeal Judgment (n 61) para. 114.

193 See, e.g., Prosecutor v Đorđević, Judgement, IT-05-87/1-A, 27 January 2014, para. 522; Kordić \& Čerkez Appeal Judgment (n 157) para. 97; Prosecutor v Martić, Judgement, IT-95-11-A, 8 October 2008, para. 35; Mrkšić Appeal Judgment (n 191) para. 35; Case 001 Appeal Judgment (n 64) para. 304; Bemba Trial Judgment (n 3) para. 152; Prosecutor v Taylor, Judgement, SCSL-03-01-T, 18 May 2012, para. 508 .

${ }^{194}$ See e.g., Akayesu Trial Judgment (n 186) para. 582; Prosecutor v Limaj et al., Judgement, IT-03-66T, 30 November 2005, para. 223-234; Prosecutor v Brdjanin, Judgement, IT-99-36-T, 1 September 2004, para. 134; Prosecutor v Krajišnik, Judgement, IT-00-39-T, 27 September 2006, para. 706; Prosecutor v Halilović, Judgement, IT-01-48-T, 16 November 2005, para. 34; Prosecutor v Bisengimana, Judgement and Sentence, ICTR-00-60-T, 13 April 2006, para. 48-49; Prosecutor v Seromba, Judgement, ICTR2001-66-I, 13 December 2006, para. 358; Prosecutor v Simba, Judgement and Sentence, ICTR-01-76-T, 13 December 2005, para. 421; Prosecutor v Muvunyi, Judgement, ICTR-00-55A-T, 11 February 2010, para. 512; Prosecutor $v$ Ndindiliyimana et al., Judgement, ICTR-00-56-T, 17 May 2011, para. 2095. 
attacked. This was best demonstrated in the Mrkšić case, where the trial judgment held that a victim of a crime against humanity must be a 'civilian'. ${ }^{195}$ Consequently, the Chamber acquitted the accused of crimes against humanity for the removal and murder of 194 men from Vukovar hospital - 181 of whom were members of the Croatian armed forces who were hors de combat ${ }^{196}$ - because of their the status of the victims as members of the armed forces. ${ }^{197}$ The Mrkšić Appeals Judgment subsequently tempered the narrowness of the Trial Chamber's conclusion, holding that nothing in the text of Article 5 of the ICTY Statute required that individual victims of crimes against humanity be civilians. ${ }^{198}$ The Appeals Chamber thereby overturned the Trial Chamber's finding, declaring that the status of victims as civilians is relevant to the question of whether the jurisdictional requirement of a civilian population being the primary target of an attack is met, ${ }^{199}$ but that once established, non-civilians could be considered victims of crimes against humanity. ${ }^{200}$

The implications of the narrow approach adopted in the Blaškić Appeal Judgment has caused jurisprudence to evolve from combatants not being considered as victims, ${ }^{201}$ to 'there [being] no legal requirement that a certain proportion of the victims of the underlying crime be civilians', ${ }^{202}$ to the broadest extent possible, namely that 'the victims of the underlying crime do not have to be civilians.' ${ }^{203}$ These judgments demonstrate the ICTY's effort to close the possible protection deficit of interpreting 'civilian' in accordance with Article 50(1) of Additional Protocol I - by relying on an expansive interpretation of 'civilian population' under Article 50(3). ${ }^{204}$ While this

\footnotetext{
195 Prosecutor v Mrkšić et al., Judgement, IT-95-13/1-T, 27 September 2007, para. 463.

${ }^{196}$ Mrkšić Appeal Judgment (n 191) paras 3, 36.

${ }^{197}$ Mrkšić Trial Judgment (n 195) para. 83. The killings also took place in the context of a widespread and systematic attack, see, para. 480.

${ }^{198}$ Mrkšić Appeal Judgment (n 191), para. 29, relying on Prosecutor v Martić, Judgement, IT-95-11-A, 8 October 2008, para. 307.

${ }^{199}$ Mrkšić Appeal Judgment (n 191) paras 30-31.

200 Ibid., para. 32.

${ }^{201}$ See, Kordić \& Čerkez Appeal Judgment (n 157) paras 458, 461.

${ }^{202}$ See e.g., Prosecutor v Blagojević \& Jokić, Judgement, IT-02-60-T, 17 January 2005, para. 544; Tadić Trial Judgment (n 171) para. 638; Prosecutor v Semanza, Judgement, ICTR-97-20-T, 15 May 2003, para. 330; Prosecutor v Kayishema \& Ruzindana, Judgement, ICTR-95-1-T, 21 May 1999, para. 128; Limaj Trial Judgment (n 194) para. 186; Prosecutor v Galić, Judgement, IT-98-29-T, 5 December 2003, para. 143; Bagilishema Trial Judgment (n 188) para. 79; Akayesu Trial Judgment (n 186) para. 582; Blaškić Appeal Judgment (n 190) para. 113; Prosecutor v Popović et al., IT-05-88-A, 30 January 2015, para. 569 ${ }^{203}$ Prosecutor v Tolimir, Judgement, IT-05-88/2-A, 8 April 2015, para. 142.

${ }^{204}$ See, e.g., Case 001, Judgment, 001/18-07-2007/ECCC/TC, 26 July 2010, paras 322, 325; Tadić Trial Judgment (n 171) para. 638; Akayesu Trial Judgment (n 186) para. 582; Prosecutor v Muhimana, Judgement, ICTR-95-1B-T, 28 April 2005, para. 528; Prosecutor v Gacumbitsi, Judgement, ICTR-2001-
} 
'work-around solution' serves to provide legal protection to all victims, it is clearly a way out of an otherwise unsatisfactory situation. ${ }^{205}$ Moreover, it creates a protection lacuna where the underlying attack does not satisfy the chapeau requirement of an 'attack against a civilian population'. Take, for example, a peacetime attack by a government exclusively aimed at a section of its own armed forces who come from a rival or different political, ethnic, or religious group. There, the victims of that attack would not have any protection under crimes against humanity, as the chapeau has not been met according to the international humanitarian law -based definition of 'civilian'. The greater the numbers and the more specific the manner of the attack against members of one's own armed forces, the less protection crimes against humanity allows when interpreted under the current international humanitarian law framed definition. As demonstrated by the above discussion, these soldiers could be protected under limited circumstances through international humanitarian law either under the concept of hors de combat or allegiance. Therefore, there is technically a greater level of protection under international humanitarian law than under crimes against humanity in certain circumstances, despite crimes against humanity seemingly covering a broader range of potential victims than international humanitarian law. ${ }^{206}$

On top of this, the ad hoc tribunals, by interpreting the terms 'civilian' and 'civilian population' through the lens of international humanitarian law, have effectively created a distinction in the realm of crimes against humanity between 'civilians' and 'victims' - where no such dichotomy is otherwise evident. Arguably, applying the international humanitarian law definition of 'civilian' (as excluding members of the armed forces) makes the concept of crimes against humanity illogical. Under this interpretation, civilians must be the primary target of an attack in order to prove the chapeau element, but no victims of that attack have to be civilians in order to attribute responsibility. Interpreting the requirements of crimes against humanity in light of what the regime seeks to protect and focusing on the specific situation of the victim rather than his or

64-T, 17 June 2004, para. 302; Blaškić Trial Judgment (n 187) para. 214; Prosecutor v Galić, Judgement, IT-98-29-A, 30 November 2006, para. 144; Prosecutor v Milutinović et al., Judgement, IT-05-87-T, 26 February 2009, para. 146; Prosecutor v Milošević, Judgement, IT-98-29/1-A, 12 November 2009, para. 59; Muvunyi Trial Judgment (n 194) para. 513; Prosecutor v Katanga, Judgment pursuant to article 74 of the Statute, ICC-01/04-01/07, 7 March 2014, para. 1105; Blaškić Appeal Judgment (n 190) para. 15; Prosecutor v Gbagbo, Decision on the confirmation of charges against Laurent Gbagbo, ICC-02/1101/11, 12 June 2014, para. 63.

205 Sadat, Putting Peacetime First (n 176) 210.

${ }^{206}$ Hall and Ambos (n 175) 175. 
her formal status obviates the need for the legal gymnastics required by the ill-suited transposition of international humanitarian law definitions, as well as reflecting the inclusive origins of the crimes against humanity doctrine in post-World War II texts. International humanitarian law still has a place in this suggested interpretative framework, namely when assessing whether the individual is a 'lawful target', rather than whether that person is a victim, ensuring that there is no situation in which a legitimate act under international humanitarian law becomes subject to a prosecution as a crime against humanity.

\section{Conclusion}

The mistreatment of members of a party to a conflict by their own fellow forces has been little analysed in international criminal law cases prior to the emergence of the question at the ICC - in relation to international humanitarian law - and the ECCC regarding crimes against humanity. Though not directly addressed in the foundational documents and jurisprudence upon which these two legal regimes were constructed, the scope of the protection provided for in each sphere is open to an interpretation that creates a legal lacuna that would leave such individuals vulnerable to be targeted with impunity under international criminal law for those responsible. The question can be approached in different ways in both legal spheres, as seen in the varying approaches adopted by the Pre-Trial Chamber, Trial Chamber and Appeals Chamber at the ICC, and the numerous views espoused by amici curiae prior to the ICIJ's decision at the ECCC, as well as the decision itself.

We propose an approach common to both regimes that involves a case-by-case assessment of whether the specific situation of the individual at the operative time is such that it requires legal protection. International law, and particularly human rights law, has grown since World War II to inhabit all areas involving the treatment of individuals, such that the sovereignty of the domestic realm is no longer inviolable in the face of universal concern regarding the treatment of individuals. This necessarily includes members of armed forces. This article does not seek to disregard state sovereignty. Rather it recognises the practical realities of conflict and violent state repression, in which certain conduct remains within domestic legal competence until such times as the mistreatment of individuals reaches a certain threshold beyond which it becomes a matter of concern to international law. Allowing for the punishment under 
international humanitarian law and crimes against humanity of members of armed forces or groups for crimes committed vis-à-vis individuals on their own side is in keeping with the nature and purpose of the protection envisaged by international law.

Proceeding in the manner set out above ensures that members of a party's own forces are not the victims of international crimes with no accountability possible under international criminal law. Individuals in an armed group or force are legally vulnerable to attack by any hostile opposing force. Such status must not simultaneously deprive individuals of protection under international criminal law where the group or armed force to which they belong and whom they legitimately expect or practically depend upon to ensure their safety are responsible for gross mistreatment and deprivation of their individuals rights. The approach outlined demonstrates a legal basis for this which is rooted in seminal international law texts and practice and ensures that international criminal law covers those who need protection, irrespective of whether they have voluntarily joined or are enlisted or coerced into a fighting force, against the worst delicts of our time. 